\title{
Auditory screening in the elderly: comparison between self-report and audiometry
}

Cláudia Maria Valete-Rosalino ${ }^{1}$, Suely Rozenfeld ${ }^{2}$ Key words: hearing loss, aged, questionnaires,
audiometry, validity.

\section{Summary}

\section{$\mathrm{D}$} espite its high prevalence in the aged, hearing loss has been poorly investigated. Audiometry is the gold standard for evaluation of hearing loss, but large-scale use of the procedure involves operational difficulties. Thus, self-report may be an alternative. Aim: To determine if a single global question is valid for use in epidemiologic research. Study design: Systematic review. Material and method: A search of the medical literature from 1990 to 2004 was performed using MEDLINE and LILACS. The references of the articles identified in the electronic search were also reviewed. Study Selection and Data Extraction: The articles that compared the results obtained with self-report to a single global question with those obtained by pure tone audiometry were selected. Data about the prevalence of hearing loss, and sensitivity, specificity and predictive values were extracted. Data Synthesis: Ten longitudinal studies were included. A single global question seems to be an acceptable indicator of hearing loss, sensitive and reasonably specific, mainly if the hearing loss is identified as the tone average that includes frequencies up to 2 or $4 \mathrm{kHz}$, at $40 \mathrm{dBHL}$ level, in the best ear. Conclusion: A single global question shows good performance in identifying older persons with hearing loss and can be recommended for an epidemiologic study if audiometric measurements cannot be performed.

${ }^{1}$ Physician, Post-graduation in Otorhinolaryngology, Specialist in Otorhinolaryngology, Master in Otorhinolaryngology; Ph.D. studies in Public Health (Technologist/ Professor) - Service of Otorhinolaryngology, Instituto de Pesquisas Clínicas Evandro Chagas - FIOCRUZ; Department of Otorhinolaryngology and Ophthalmology - Federal University of Rio de Janeiro; Ph.D. studies under course, Escola Nacional de Saúde Pública - FIOCRUZ.

${ }^{2}$ Physician, Master and Ph.D. in Public Health (Researcher) - Department of Epidemiology and Health Quantitative Methods - Escola Nacional de Saúde Pública - FIOCRUZ. Address correspondence to: Cláudia Maria Valete-Rosalino, Fundação Oswaldo Cruz, Instituto de Pesquisa Clínica Evandro Chagas, Serviço de Otorrinolaringologia. Av. Brasil 4365, 21045-900 Rio de Janeiro, RJ, Brazil; Tel: 5521 38659525, fax:+55 21 38659541, e-mail: cmvalete@ipec.fiocruz.br Article submited on March 08, 2005. Article accepted on April 01, 2005. 


\section{INTRODUCTION}

Considering the age of 60 years as the dividing line between elderly and non-elderly, we observed based on IBGE data (Brazilian Institute of Geography and Statistics) that there has been percentage increase in number of elderly people (60 years and over) in Brazil, from $5.07 \%$ in 1970 to $8.56 \%$ in $2000{ }^{1}$. The number of elderly patients went up from 3 million in 1960 to 7 million in 1975, to 14 million in 2002 (a 500\% increase within 40 years). It is estimated that it will reach 32 million by $2020^{2}$. If there are further advances in mortality drop at advanced ages, this process will be even further enhanced ${ }^{1}$.

Among pathologies whose frequency increases with aging, we can include those related with inner ear. Hearing loss is the third most prevalent chronic condition among American elderly patients, third to hypertension and arthritis 3. In Brazil, studies have shown a prevalence of hearing loss in the elderly that ranges from 20 to $85 \%{ }^{4-7}$. Hearing loss has been associated with negative psychosocial impact ${ }^{8}$, with inability to perform heavy home chores ${ }^{9}$ and increase in occupational accidents ${ }^{10}$. Auditory sensorial loss not corrected by hearing aids is associated with loss of selfsufficiency in daily living activities and social relationship impairment in the elderly, plus increased mortality in males ${ }^{11}$. The wish to wear a hearing aid is not associated with severity of loss, but rather with functional status of the subject, being higher among more independent subjects ${ }^{8}$.

Despite the high prevalence among elderly patients, hearing loss is one of the problems not investigated during routine medical examination in this age range ${ }^{12}$. Screening can be useful in identifying primary health care, given that the onset is insidious and that patients are frequently unaware of it. Audiometry is the gold standard test, but its conduction is sometimes hindered in some regions owing to problems of access, reference and reimbursement. Thus, many clinicians rely on self-administered questionnaires ${ }^{13}$. As to research studies, large-scale trials of auditory status may provide clues on temporal trends of prevalence of hearing loss and contribute to the identification in geographical areas and subgroups of risk populations (gender, race and ethnicity). These investigations may be a quick and cheap way of providing estimates to large populations, in which expenses (audiometric equipment and trained personnel) and time restrictions are a concern ${ }^{14}$. Generic isolated issues on hearing have also been used in epidemiological studies. Self-report can also be an indicator of hearing loss and it is quick and cheap to administer ${ }^{15}$.

Considering that audiometry is the gold standard for hearing loss detection and requires trained team, soundproof booth and equipment, hindering its execution in large scale, our final goal was to determine whether one single global question would be valid to be used in epidemiological research studies. This paper aimed at reviewing studies whose purposes were to compare results obtained with use of isolated questions and results obtained through pure tone audiometry in assessment of hearing loss in the elderly.

\section{MATERIAL AND METHOD}

\section{Identification and selection of studies}

We conducted a literature review on databases MEDLINE and LILACS, in the period between 1990 and 2004 to retrieve articles comparing results obtained in the assessment of hearing loss in the elderly through self-report using one single global question and pure tone audiometry. In the electronic search we used the terms hearing loss, bearing impairment, deafness, presbycusis, questionnaires, self-report, question, validity, audiometry, isolated or in combination and accepted texts in all languages. We also analyzed articles cited in the references of other articles identified in the electronic search. We selected 10 articles from MEDLINE and none from LILACS. We excluded one article because it did not provide isolated data on validity of the use of one single global question on hearing loss assessment compared to pure tone audiometry ${ }^{16}$, one article that did not specify the results in the elderly ${ }^{17}$, and another one that did not compare the results of one single question with audiometry ${ }^{18}$.

\section{Data extraction}

We extracted data on prevalence of hearing loss observed by audiometry, estimated loss by the question and difference between prevalence of observed and estimated hearing loss. Sensitivity, specificity and predictive values of hearing loss assessment through one single global question in comparison to audiometry were also included. One study presented estimate of odds ratio (OR) of the question concerning hearing loss measured by audiometry and another one assessed the association between the question and the mean thresholds in different frequencies.

\section{Characteristics of analyzed studies}

In Table 1 we can see the description of general characteristics of analyzed studies. We located 10 transversal studies and seven had population basis ${ }^{13-15,19-22}$, one was conducted on nursery home patients ${ }^{23}$, one on workers in a technology company ${ }^{24}$ and one was hospital-based ${ }^{8}$. Studies involved samples that ranged from 198 to 12,495 subjects, except for one study that included only 63 subjects $^{8}$. All studies included subjects aged 60 years or more, and one of them included only women ${ }^{20}$.

Pure tone audiometry criteria varied according to frequency, intensity and assessed ears. Seven studies assessed pure tone mean (MT), with variation of frequencies used in the calculation between $0.5,1,2,3$ and $4 \mathrm{kHz}{ }^{14,15,19-21,23,24}$. Three studies used individual thresholds of frequencies, and two of them were 1 and $2 \mathrm{kHz}^{13,21}$ and the other was 1 and 3 
$\mathrm{kHz}^{8}$. One study used isolated thresholds of frequencies 0.5 , $1,2,4$ and $8 \mathrm{kHz}$ and compared means of thresholds of each frequency with self-report of hearing loss ${ }^{22}$. Intensity of stimulus used as cut-off point was $25 \mathrm{~dB}$ hearing level (dBHL) in seven studies ${ }^{14,15,19-21,23,24}$. Four studies used 60dB HL as cut-off point ${ }^{15}$ and the other one used intensities of 30 and $50 \mathrm{~dB} \mathrm{HL}^{8}$. Seven studies used the best ear in the assessment of hearing loss ${ }^{15,19,20-24}$ and three used the worst ear ${ }^{14,20,22}$. Three studies considered both ears or the worst ear ${ }^{8,13,21}$.

The questions used were similar one to the other, and five studies used questions with yes-no questions ${ }^{8,13,19-}$
${ }^{21}$, two considered the answered "I don't know" and excluded it from the study ${ }^{14,15}$, one considered the answer "I don't know" as positive to the hearing loss and analyzed it together with "yes" ${ }^{23}$, one considered the response "occasionally" together with "yes" in the analysis of estimated prevalence of hearing loss, but considered it as isolated concerning the other assessments ${ }^{22}$. Other two studies used multiple response questions, and Hashimoto et al. (2004) ${ }^{24}$ considered as negative to the hearing loss only the option "no hearing problem", whereas Nondahl et al. (1998) ${ }^{14}$ considered as positive to the hearing loss the options "fair" and "poor".

Table 1. General characteristics of validation studies of the hearing loss questionnaire for the elderly.

\begin{tabular}{|c|c|c|c|}
\hline $\begin{array}{l}\text { Author, year, } \\
\text { country }\end{array}$ & Sample & \multicolumn{2}{|c|}{ Criteria of hearing loss for pure tone audiometry Question } \\
\hline $\begin{array}{l}\text { Gates et al., } \\
1990^{19} \\
\text { USA }\end{array}$ & $\begin{array}{l}\mathrm{N}=1662 \\
\text { Age: } 63-95 \text { years; Mean: } 73 \text { years } \\
\text { Gender: } 41 \%(\mathrm{M}) \text { and } 59 \%(\mathrm{~F})\end{array}$ & $\begin{array}{l}\text { MT 0,5, 1, } 2 \mathrm{kHz}>25 \mathrm{~dB} \text { NA, best ear } \\
\text { MT 0,5, 1, } 2 \text { and } 3 \mathrm{kHz}>25 \mathrm{~dB} \text { NA, best } \\
\text { ear }\end{array}$ & $\begin{array}{l}\text { Dou you have a hearing } \\
\text { problem now? }\end{array}$ \\
\hline $\begin{array}{l}\text { Clark et al., } \\
1991^{20} \\
\text { USA }\end{array}$ & $\begin{array}{l}\mathrm{N}=267 \\
\text { Age: } 60-85 \text { years } \\
\text { Gender: } 100 \%(\mathrm{~F})\end{array}$ & $\begin{array}{l}\text { MT } 1 \text { and } 2 \mathrm{kHz} \text { or } 1,2,3 \text { and } 4 \mathrm{kHz} \geq 25 \mathrm{~dB} \mathrm{HL} \\
\text { or } \geq 40 \mathrm{~dB} \mathrm{HL} \text {, best ear and worst ear }\end{array}$ & $\begin{array}{l}\text { Would you say that you have } \\
\text { any difficulty hearing? }\end{array}$ \\
\hline $\begin{array}{l}\text { Voeks et al., } \\
1993^{23} \\
\text { USA }\end{array}$ & $\begin{array}{l}\mathrm{N}=198 \\
\text { Age: } \mathrm{NI} \text {; Mean: } 72.4 \pm 11.4 \text { years } \\
\text { Gender: } 81.8 \%(\mathrm{M}) \text { and } 18.2 \%(\mathrm{~F})\end{array}$ & MT $0,5,1$ and $2 \mathrm{kHz}>25 \mathrm{~dB} \mathrm{HL}$, best ear & Do you have trouble hearing? \\
\hline $\begin{array}{l}\text { Reuben et al., } \\
1998^{21} \\
\text { USA }\end{array}$ & $\begin{array}{l}\mathrm{N}=917 \\
\text { Age: } 55-74 \text { years } \\
\text { Gender: } \mathrm{NI}\end{array}$ & $\begin{array}{l}\text { thresholds } 1 \text { to } 2 \mathrm{kHz}>40 \mathrm{dBHL} \text { in both ears } \\
\text { or thresholds } 1 \text { and } 2 \mathrm{kHz}>40 \\
\mathrm{dBHL} \text { in one ear } \\
\text { MT } 1,2 \text { e } 4 \mathrm{kHz} \text { e" } 25 \mathrm{dbNA} \text {, best ear }\end{array}$ & $\begin{array}{l}\text { Have you ever had deafness } \\
\text { or trouble hearing with one or } \\
\text { both ears? }\end{array}$ \\
\hline $\begin{array}{l}\text { Nondahl et al., } \\
1998^{14} \\
\text { USA }\end{array}$ & $\begin{array}{l}\mathrm{N}=3556 \\
\text { Age: } 48-92 \text { years; Mean: } 65.8 \text { years } \\
\text { Gender: } 42.3 \%(\mathrm{M}) \text { and } 57.7 \%(\mathrm{~F})\end{array}$ & $\begin{array}{l}\text { MT } 0,5,1,2 \text { and } 4 \mathrm{kHz}>25 \mathrm{~dB} \mathrm{HL} \text {, worst } \\
\text { ear }\end{array}$ & $\begin{array}{l}\text { 1. Do you feel you have a } \\
\text { hearing loss? } \\
\text { 2. In general, would you say } \\
\text { your hearing is (1) excellent, } \\
\text { (2) very good, (3) good, } \\
\text { (4) fair, (5) poor }\end{array}$ \\
\hline $\begin{array}{l}\text { Sindhusake et al. } \\
2001^{15} \\
\text { Australia }\end{array}$ & $\begin{array}{l}\mathrm{N}=2015 \\
\text { Age: } 55-100 \text { years } \\
\text { Gender: } 42.6 \%(\mathrm{M}) \text { and } 57.4 \%(\mathrm{~F})\end{array}$ & $\begin{array}{l}\text { MT } 0,5,1,2 \text { and } 4 \mathrm{kHz}>25 \mathrm{~dB} \mathrm{HL},>40 \mathrm{~dB} \mathrm{HL} \\
\text { and }>60 \mathrm{~dB} \mathrm{HL} \text {, best ear }\end{array}$ & $\begin{array}{l}\text { Do you feel you have a } \\
\text { lhearing oss? }\end{array}$ \\
\hline $\begin{array}{l}\text { Gates et al., } \\
2003^{13} \\
\text { USA }\end{array}$ & $\begin{array}{l}\mathrm{N}=546 \\
\text { Age: } 72-94 \text { years; Mean: } 78.3 \pm 4.1 \text { years } \\
\text { Gender: } 35.5 \%(\mathrm{M}) \text { and } 64.5 \%(\mathrm{~F})\end{array}$ & $\begin{array}{l}\text { thresholds } 1 \text { or } 2 \mathrm{kHz} \geq 40 \mathrm{dBHL} \text { in both ears } \\
\text { or thresholds } 1 \text { and } 2 \mathrm{kHz} \geq 40 \\
\mathrm{dBHL} \text { in one ear }\end{array}$ & $\begin{array}{l}\text { Do you have a hearing } \\
\text { problem now? }\end{array}$ \\
\hline $\begin{array}{l}\text { Uchida et al., } \\
2003^{22} \\
\text { Japan }\end{array}$ & $\begin{array}{l}N=2150 \\
\text { Age: } 40-79 \text { years } \\
N=539: 50-59 \text { years; } N=544: 60-69 \text { years; } \\
N=529: 70-79 \text { years } \\
\text { Gender: } 51.3 \%(\mathrm{M}) \text { and } 48.7 \%(F)\end{array}$ & $\begin{array}{l}\text { thresholds } 0,5,1,2,4 \text { and } 8 \mathrm{kHz} \text { best ear } \\
\text { and worst ear }\end{array}$ & $\begin{array}{l}\text { Do you feel you have } \\
\text { hearing loss? }\end{array}$ \\
\hline $\begin{array}{l}\text { Hashimoto et al., } \\
2004^{24} \\
\text { Japan }\end{array}$ & $\begin{array}{l}\mathrm{N}=12.495 \\
\text { Age: over } 30 \text { years; Mean: } 47.8 \pm 7.0 \\
\mathrm{~N}=5.095: 50-59 \text { years; } \mathrm{N}=343 \text { : over } 60 \\
\text { years } \\
\text { Gender: } 92.7 \%(\mathrm{M}) \text { and } 6.3 \%(\mathrm{~F})\end{array}$ & MT 1 and $4 \mathrm{kHz} \geq 25 \mathrm{dBHL}$, Best ear & $\begin{array}{l}\text { Do you have difficulty in } \\
\text { hearing? } 0=\text { no hearing } \\
\text { problem; } 1=\text { same as before; } \\
2=\text { progressive; } 3=\text { getting } \\
\text { worse }\end{array}$ \\
\hline $\begin{array}{l}\text { Wu et al., } 2004^{8} \\
\text { Singapore }\end{array}$ & $\begin{array}{l}\mathrm{N}=63 \\
\text { Age: } 62-90 \text { years; Median: } 79 \text { years } \\
\text { Gender: } 39.7 \%(\mathrm{M}) \text { and } 60.3 \%(\mathrm{~F})\end{array}$ & $\begin{array}{l}\text { thresholds } 1 \text { or } 3 \mathrm{kHz},>30 \mathrm{~dB} \mathrm{HL} \text { or }>50 \\
\mathrm{~dB} \mathrm{HL} \text {, one ear }\end{array}$ & $\begin{array}{l}\text { Do you think you have a } \\
\text { hearing problem? }\end{array}$ \\
\hline
\end{tabular}




\section{Synthesis of Data in Analyzed Studies}

Table 2 presents observed and estimated prevalence, sensitivity, specificity and predictive values found in different studies.

Observed prevalence by pure tone audiometry ranged from $2 \%\left(>60 \mathrm{dBHL}^{15}\right)$ to $83 \%{ }^{8}$. Excluding the study by Hashimoto et al. (2004) ${ }^{24}$, who studied subjects over the age of 30 years, the observed prevalence was higher when using cut-off intensity of $25 \mathrm{dBHL}$ (29 to 60\%) than when using cut-off points of $40 \mathrm{dBHL}$ (11 to 27\%) and 60 dBHL (2\%). Excluding the analysis of cut-off point of 60dBHL, studies assessed up to the frequency of $2 \mathrm{kHz}$ presented lower prevalence values (11 to 54\%) than the ones that assessed up to $4 \mathrm{kHz}$ (18 to 60\%). Considering the assessed ear, the best ear presented lower values of observed prevalence (11 to $54 \%$ ) than the worst ear (18 to 60\%). Estimated prevalence ranged from $6.1 \%$ (subjects aged over 60 years by Hashimoto et al., 2004) to $60 \% 0^{23}$. In absolute numbers, the difference in observed and estimated prevalence ranged from 0.9 ( $50-59$ years by Hashimoto et al., 2004) to $49\left(>60 \mathrm{dBHL}^{15}\right)$. In other words, the observed prevalence increased with reduction of intensity cut-off point, with increase of studied frequency and when they considered the worst ear.

Sensitivity ranged from $14 \%$ (over the age of 60 years $\left.{ }^{24}\right)$ to $100 \%\left(>60 \mathrm{dBHL}^{15}\right)$ and specificity ranged from $50 \%$ $\left(>60 \mathrm{dBHL}^{15}\right.$ ) to $95 \%$ (over the age of 60 years $^{24}$ ). Positive predictive value (PPV) ranged from $5 \%\left(>60 \mathrm{dBHL}^{15}\right)$ to $97 \%{ }^{8}$ and negative predictive value (NPV) ranged from $31 \%$ to $100 \%$ ( $\left.>60 \mathrm{dBHL}^{15}\right)$. We observed that sensitivity of both questions with multiple-choice responses was lower, and for this reason we did not include their results in the analysis that follows. As to studied frequencies, Clark et al. (1991) ${ }^{20}$ were the only ones that presented results with two distinct criteria owing to used frequencies of hearing loss through pure tone audiometry. The results suggested that the use of pure tone mean of frequencies 1, 2, 3 and $4 \mathrm{kHz}$ presented lower values of sensitivity and NPV and higher values of specificity and PPV, comparing the pure tone mean of frequencies 1 and $2 \mathrm{kHz}$. Sensitivity was higher when using $40 \mathrm{dBHL}$ as cut-off point (70 to 93\%) and it was lower when the cut-off point was $25 \mathrm{dBHL}$ ( 51 to $89.9 \%$ ). Conversely, specificity was higher using the cut-off point $25 \mathrm{dBHL}(50.6$ to $88 \%$ ) than using $40 \mathrm{dBHL}$ ( 56 to $77 \%$ ). As to used ear, the best ear had higher values of sensitivity (56 to 100\%) than the worse ear (51 to 81\%), and the worst ear had higher values of specificity ( 71 to $88 \%$ ) than the best ear (50 to 86.9\%). PPV was higher when using $25 \mathrm{dBHL}$ (62.2 to 86\%) as cut-off point and it was lower when the cut-off point was 40 dBHL below (25 to 54\%). NPV was higher when using $40 \mathrm{dBHL}$ ( 87 to $98 \%$ ) as cut-off point and it was lower when the cut-off point was 25 dBHL lower ( 43 to $93.8 \%$ ). As to used ear, the best ear had the highest values of negative predictive value (58.2 to $98 \%$ ) than the worst ear ( 43 to
95\%), and the worst ear took to higher positive predictive value ( 40 to $86 \%$ ) than the best ear ( 25 to $79.8 \%$ ). The only study that used cut-off point at $60 \mathrm{dBHL}$ presented the highest values of sensitivity and NPV (100\%) and the lowest values of specificity (50\%) and PPV (5\%).

Gates et al. (1990) ${ }^{19}$ referred that the proportion of male that detected hearing problem (50\%) was higher than that of female subjects $(35 \%)\left(C^{2}=38.58, \mathrm{p}<0.0001\right)$. To both men and women, prevalence of self-reported hearing impairment increased with each 5-year increase in age group (women: $\mathrm{C}^{2}=57.2, \mathrm{p}<0.001$; men: $\mathrm{C}^{2}=18.1, \mathrm{p}=0.02$ ). Pure tone mean in the best ear in 683 patients that reported an auditory problem was significantly worse than in 979 cases that did not report hearing problems. Pure tone mean in the best ear was significantly higher among men (MT 0.5-2 kHz= $22.0 \pm 0.52 ;$ MT $0.5-3 \mathrm{kHz}=27.9 \pm 0.53)$ than among women (MT $0.5-2 \mathrm{kHz}=20.4 \pm 0.42 ;$ MT $0.5-3 \mathrm{kHz}=22.7 \pm 0.43$ ). As a result of increased age, there is generalized worsening of thresholds in all frequencies, especially in higher ones. Authors detected a significant difference $\left(C^{2}=6.23, \mathrm{p}=0.013\right)$ between proportion of men (32.5\%) and women (26.7\%) that were classified as having hearing loss with MT 0.5-2 $\mathrm{kHz}$.

Reuben et al. (1998) $)^{21}$ observed in people with positive self-report to hearing loss a chance almost 10 times higher (OR=9.8, CI: 7.8-12.4) of having a hearing loss compared to people whose self-report was negative, according to the criteria of thresholds 1 or $2 \mathrm{kHz}>40 \mathrm{dBHL}$ in both ears or thresholds 1 and $2 \mathrm{kHz}>40 \mathrm{dBHL}$ in one ear, and almost five times higher ( $\mathrm{OR}=4.8, \mathrm{CI}$ : 4.0-5.9) according to criteria of pure tone mean of 1,2 and $4 \mathrm{kHz} e \cdot 25 \mathrm{dBHL}$ in the best ear. Observed prevalence of hearing loss was significantly higher in men, in the older groups and when cut-off criterion was at $25 \mathrm{dBHL}$.

Nondahl et al. (1998) $)^{14}$ checked the presence of $71 \%$ accuracy in question 1 (binary response) and accuracy of $70 \%$ in question 2 (multiple category of responses). They observed that questions had sensitivity and PPV that were higher in men and specificity, NPV and general accuracy that were higher in women. As to age, they observed that questions had greater sensitivity in the younger group (4864 years), as well as in most cases they also presented higher accuracy and better estimate of prevalence in the group.

Sindhusake et al. (2001) ${ }^{15}$ reported results of sensitivity and specificity that were separated by gender and age and observed that they were minimally affected. The question presented higher sensitivity and lower specificity in male subjects, and higher sensitivity and specificity in the younger group (below 70 years).

Uchida et al. (2003) ${ }^{22}$ observed that prevalence of self-reported hearing loss was significantly higher in older subjects and in both genders and that it was higher in women aged 40 to 59 years. They also observed statistically significant correlation between self-report of hearing loss and pure tone 
Table 2. Prevalence of hearing loss and validity of one single question questionnaire.

\begin{tabular}{|c|c|c|c|}
\hline Author, Year & $\begin{array}{l}\text { Observed prevalence of hearing loss by } \\
\text { pure tone audiometry (\%) } \\
\text { Estimated prevalence of hearing loss } \\
\text { by question (\%) } \\
\text { Difference between observed and estimated } \\
\text { hearing loss (\%) }\end{array}$ & $\begin{array}{l}\text { Sensitivity (\%) and } \\
\text { Specificity (\%) }\end{array}$ & $\begin{array}{l}\text { Positive Predictive Value (\%) } \\
\text { and Negative Predictive Value (\%) }\end{array}$ \\
\hline $\begin{array}{l}\text { Gates et al., } \\
1990^{19}\end{array}$ & $\begin{array}{l}\mathrm{PO}(0,5-2 \mathrm{kHz})=29 \text { e PO }(0,5-3 \mathrm{kHz})=42 \\
\mathrm{PE}=41 \\
\mathrm{PO}-\mathrm{PE}(0,5-2 \mathrm{kHz})=-12 \text { and } \mathrm{PO}-\mathrm{PE}(0,5-3 \mathrm{kHz})=1\end{array}$ & $\begin{array}{l}\mathrm{S}(0,5-2 \mathrm{kHz})=89,93 \\
\mathrm{E}(0,5-2 \mathrm{kHz})=86,93\end{array}$ & $\begin{array}{l}\operatorname{VPP}(0,5-2 \mathrm{kHz})=79,80 \\
\operatorname{VPN}(0,5-2 \mathrm{kHz})=93,77\end{array}$ \\
\hline $\begin{array}{l}\text { Clark et al., } \\
1991^{20}\end{array}$ & $\begin{array}{l}\text { PO - Best ear } \\
\geq 25 \mathrm{dBNA}:(1-2 \mathrm{kHz})=34 \text { and }(1-4 \mathrm{kHz})=45 \\
\geq 40 \mathrm{dBNA}:(1-2 \mathrm{kHz})=11 \text { and }(1-4 \mathrm{kHz})=18 \\
\text { PO-Worst ear } \\
\geq 25 \mathrm{dBNA}:(1-2 \mathrm{kHz})=42 \text { and }(1-4 \mathrm{kHz})=60 \\
\geq 40 \mathrm{dBNA}:(1-2 \mathrm{kHz})=18 \text { and }(1-4 \mathrm{kHz})=27 \\
\mathrm{PE}=35 \\
\text { PO-PE-Best ear } \\
\geq 25 \mathrm{dBNA}:(1-2 \mathrm{kHz})=-1 \text { and }(1-4 \mathrm{kHz})=10 \\
\geq 40 \mathrm{dBNA}:(1-2 \mathrm{kHz})=-24 \text { and }(1-4 \mathrm{kHz})=-17 \\
\text { PO-PE-Worst ear } \\
\geq 25 \mathrm{dBNA}:(1-2 \mathrm{kHz})=7 \text { and }(1-4 \mathrm{kHz})=25 \\
\geq 40 \mathrm{dBNA}:(1-2 \mathrm{kHz})=-17 \text { and }(1-4 \mathrm{kHz})=-8\end{array}$ & $\begin{array}{l}\text { Worstear } \\
\geq 25(1-2 \mathrm{kHz}): S=58 ; E=82 \\
\geq 25(1-4 \mathrm{kHz}): S=51 ; E=88 \\
\geq 40(1-2 \mathrm{kHz}): S=81 ; E=74 \\
\geq 40(1-4 \mathrm{kHz}): S=70 ; E=77\end{array}$ & $\begin{array}{l}\text { Worstear } \\
\geq 25(1-2 \mathrm{kHz}): \mathrm{VPP}=70 ; \mathrm{VPN}=73 \\
\geq 25(1-4 \mathrm{kHz}): \mathrm{VPP}=86 ; \mathrm{VPN}=43 \\
\geq 40(1-2 \mathrm{kHz}): \mathrm{VPP}=40 ; \mathrm{VPN}=95 \\
\geq 40(1-4 \mathrm{kHz}): \mathrm{VPP}=54 ; \mathrm{VPN}=87\end{array}$ \\
\hline $\begin{array}{l}\text { Voeks etal., } \\
1993^{23}\end{array}$ & $\begin{array}{l}P O=54 \\
P E=60 \\
P O-P E=-6\end{array}$ & $\begin{array}{l}S=69,2 \\
E=50,6\end{array}$ & $\begin{array}{l}\mathrm{VPP}=62,2 \\
\mathrm{VPN}=58,2\end{array}$ \\
\hline $\begin{array}{l}\text { Reuben etal., } \\
1998^{21}\end{array}$ & $\begin{array}{l}P O>40 \mathrm{dBNA}(1-2 \mathrm{kHz})=14,2 \\
\mathrm{PO} \geq 25 \mathrm{dBNA}(1-4 \mathrm{kHz})=35,1 \\
\mathrm{PE}=24 \\
\mathrm{PO}-\mathrm{PE}>40 \mathrm{dBNA}(1-2 \mathrm{kHz})=-9,8 \\
\mathrm{PO}-\mathrm{PE} \geq 25 \mathrm{dBNA}(1-4 \mathrm{kHz})=11,1\end{array}$ & ... & $\ldots$ \\
\hline $\begin{array}{l}\text { Gates et al., } \\
2003^{13}\end{array}$ & $P O=27, P E=40$ and $P O-P E=-13$ & $\mathrm{~S}=71$ and $\mathrm{E}=72$ & $\mathrm{VPP}=48$ and $\mathrm{VPN}=87$ \\
\hline $\begin{array}{l}\text { Uchida et al., } \\
2003^{22}\end{array}$ & $\begin{array}{l}\text { PE: } 50-59 \text { years }=43,4,60-69 \text { years }=49,4 \text { and } 70-79 \\
\text { years }=56,1\end{array}$ & $\ldots$ & $\ldots$ \\
\hline $\begin{array}{l}\text { Hashimoto et } \\
\text { al., } 2004^{24}\end{array}$ & $\begin{array}{l}\text { PO-Best ear: } 50-59 \text { years }=7,1 \text { and } \geq 60 \text { years }=14,9 \\
\text { PO-Worst ear: } 50-59 \text { years }=19,8 \text { and } \geq 60 \text { years }=30,9 \\
\text { PE: } 50-59 \text { years }=6,2 \text { and } \geq 60 \text { years }=6,1 \\
\text { PO-PE Best ear: } 50-59 \text { years }=0,9 \text { and } \geq 60 \text { years }=8,8 \\
\text { PO-PEWorst ear: } 50-59 \text { years }=13,6 \text { and } \geq 60 \text { years }=24,8\end{array}$ & $\begin{array}{l}50-59 \text { years: } S=23 \text { and } E=95 \\
\geq 60 \text { years: } S=14 \text { and } E=95\end{array}$ & $\begin{array}{l}50-59 \text { years: } V P P=26 \text { and } V P N=94 \\
\geq 60 \text { years: } V P P=33 \text { and } V P N=86\end{array}$ \\
\hline Wu etal., $2004^{8}$ & $\mathrm{PO}=83, \mathrm{PE}=49,2$ and $\mathrm{PO}-\mathrm{PE}=33,8$ & $\mathrm{~S}=58$ and $\mathrm{E}=91$ & $\mathrm{VPP}=97$ and $\mathrm{VPN}=31$ \\
\hline
\end{tabular}

$\mathrm{PO}=$ Observed prevalence of hearing loss by pure tone audiometry; $\mathrm{PE}$ : Estimated prevalence of hearing loss by question; $\mathrm{PO}-\mathrm{PE}$ : Difference between observed and estimated hearing loss; $\mathrm{S}=$ sensitivity; $\mathrm{E}=$ specificity; VPP= positive predictive value; VPN= negative predictive value; $\mathrm{Q} 1=$ question $1 ; \mathrm{Q} 2=$ question 2 . 
thresholds on the best and worst ears in both age groups. In other words, thresholds in the same age range and in the same frequency were significantly higher in relation to the three groups of respondents ("yes", "occasionally" and "no"), and the thresholds in the group that responded "yes" were higher than those that responded "occasionally", which in turn were higher than those that responded "no". They also observed significantly higher thresholds in men and each age range with increase of 10 years in each group of respondents.

Hashimoto et al. (2004) ${ }^{24}$ reported agreement between self-report of hearing loss and hearing loss criteria by pure tone audiometry in 90\% in the age range 50-59 years and $83 \%$ after the age of 60 years.

\section{DISCUSSION}

The present study aimed at comparing the prevalence estimates of hearing loss obtained using two methods: selfreport and audiometry. According to the analysis of the studied literature, the single global question seems to be an acceptable indicator of hearing loss which is sensitive and reasonably specific, especially when the loss is identified as being pure tone mean up to frequencies 2 or $4 \mathrm{kHz}$, at 40 dBHL on the best ear.

The comparison of hearing loss prevalence among the studies is hindered by the differences in investigated populations and in audiometric criteria used for its definition 14, 20. Prevalence of hearing loss is smaller in women and younger people ${ }^{20}$. Moreover, elderly people selected from a nursing home ${ }^{23}$ or hospital setting ${ }^{8}$ represented a fragile selected group, presenting more comorbidities than healthy elderly people from the general population, leading to increase in prevalence of hearing loss in comparison to population-based studies ${ }^{8,20}$. The discrepant results found by Hashimoto et al. (2004) ${ }^{24}$ and the other studies may be related to the population studied by the former, which comprised industry workers. Therefore, part of the studied people could have preferred to say they did not have a hearing loss in fear of losing their jobs, malingering the audiometric performance. In addition, there is also the possibility that the results had been affected by the healthyworker effect, even though the prevalence had been comparable to that of other Japanese studies ${ }^{24}$.

Definitions of hearing loss assessed by pure tone mean in the literature range according to the ear used to classify the subject (i.e., best, worst, both, right or left ear) and to frequencies included in the pure tone mean to determine the best and the worst ear ${ }^{22}$. The use of worst ear to define hearing loss results increased prevalence ${ }^{14}$. Inclusion of frequency of $4 \mathrm{kHz}$ has also increased prevalence of hearing loss ${ }^{14,23}$ given that frequencies 0.5 to $2 \mathrm{kHz}$ are considered important in the identification of the disability related with hearing, frequencies 3 and $4 \mathrm{kHz}$ are among the first ones to show hearing decrease associated with age and they are important for speech understanding, especially in noisy environment ${ }^{20}$. Even though many different definitions of hearing loss had been proposed, there is no universal acceptance, and stricter definition (low intensity as cut-off point, such as $25 \mathrm{dBHL}$ ) leads to higher prevalence of hearing loss ${ }^{19}$.

As to self-report of hearing loss comparing to pure tone audiometry classification criteria, the use of the best ear is justified by the fact that the worst ear tends to be compensated by the function of the side that has the best subjective perception ${ }^{24}$. Self-perception of hearing loss seems to be in agreement with pure tone mean of medium frequencies $(1,2,3 \text { and } 4 \mathrm{kHz})^{16}$ and it is more frequent in subjects with moderately-severe hearing loss than among those with mild loss ${ }^{8,23}$.

As to questions used, multiple-choice questions ${ }^{14,24}$ presented lower sensitivity when compared to two-option questions. The type of question used by Hashimoto et al. $(2004)^{24}$ may have caused confusion given that the answer "same as before" may have been used to mean "no hearing problem since then", even though when they classified "same as before" as having no hearing loss, there were no statistically significant differences in sensitivity and specificity of the question. Moreover, even though two-option questions had been similar one to the other, such as those used by Gates et al. (1990 ${ }^{19}$ and $\left.2003^{13}\right)$, they may have given the impression to respondents that they were more serious difficulties, which could have reduced the estimated prevalence of hearing loss ${ }^{14}$.

Voeks et al. $(1993)^{23}$ considered mistaken the response "I don't know" as a positive indication of hearing loss because they consider that this strategy conveys more sensitivity to the question, whereas other studies considered them as missing values ${ }^{14,15}$. However, in the group studied by Voeks et al. (1993) ${ }^{23}$ there were some subjects with cognitive deficit, which could have hindered the identification through a questionnaire and reduced sensitivity, given that among the three above-referred studies, the lowest sensitivity was reached by Voeks et al. (1993) ${ }^{23}$. In addition, the study by Voeks et al. (1993) ${ }^{23}$ detected more wrong responses in the group without hearing loss in the audiometry, increasing the number of false positives and justifying the low specificity found by them. They also referred that the response "yes" conveys certainty about the hearing loss, whereas "I don't know" response conveys a little more than $50 \%$ certainty ${ }^{23}$.

According to Hashimoto, Nomura and Yano $(2004)^{24}$, simple questions such as "Do you feel you have a hearing loss?" are based on subjective assessment of individual health status, and they may be distorted by other psychosomatic symptoms and mental health status. They observed higher proportion of false positives in those with more than two complaints of somatic symptoms, and wondered whether these patients would not be the most sensitive ones to all 
somatic sensations - they could have exaggerated about their hearing acuity. Thus, it might be reasonable to say that subjective hearing difficulties without objectively diagnosed impairment may reflect psychosocial problems experienced in daily communication situations at the workplace.

Screening approaches try to increase the likelihood a person with a specific dysfunction has to be identified (sensitivity), excluding those without the dysfunction (specificity). In practice, not all cases are identified (false negative), and some people without dysfunction will be misdiagnosed (false positive) ${ }^{13}$. Therefore, the more sensitive the test is for hearing loss, the higher the likelihood of false positives, and among those, many might have had some degree of dysfunction, even if they had not reached the specific criteria set by audiometry, benefiting from the referral to complete audiometric assessment ${ }^{13}$. Hashimoto et al. (2004) ${ }^{24}$ referred that discrepancy of results in relation to other studies should be related with high number of false negative results. Given that subjects in the study were relatively younger than the other studied subjects and that normal speech is produced at frequencies of about $1 \mathrm{kHz}$, even if the studied subjects had early signs of sensorineural hearing loss, they would not have been recognized in daily verbal communication. They explained the number of false negative results in the study by the fact that the proportion of subjects that complained of auditory difficulties was smaller in the group of people that had hearing loss only in the frequency of $4 \mathrm{kHz}$, compared to the group whose affection comprised 1 and $4 \mathrm{kHz}$. They reported that since audiometry was conducted yearly, they might have experienced some learning bias, and in addition, people might have stated that they had auditory difficulties because they remembered the results of hearing loss detected by previous year audiometry. It may artificially reduce false negative results and actual sensitivity could be even lower ${ }^{24}$.

As to results of the studies based on gender and age, Gates et al. (1990) ${ }^{19}$ warned to the possible role of noise exposure as basis for different etiology between men and women, whereas Uchida et al. (2003) ${ }^{22}$ observed that men tended to underestimate their hearing difficulty more than women. Sindhusake et al. (2001) $)^{15}$ did not find statistically significant differences concerning gender and age, and Nondahl et al (1998) ${ }^{14}$ did not describe whether the differences found by them had been statistically significant. The greater sensitivity to the question found in the younger group in these two studies ${ }^{14,15}$, might have been explained by low self-perception or denial of problems faced by the elderly ${ }^{8}$, considering that there is a popular belief that hearing loss is a normal part of aging and not a health problem that deserves special attention ${ }^{14}$, making them underestimate their auditory difficulty ${ }^{22}$.

As to both studies that did not present results of sensitivity, specificity and predictive values, Reuben et al. $(1998)^{21}$ conducted a study in the 70's and the traditional trend poses a risk to generalization of data on prevalence and validity of the study, because they used a relatively young sample, maximum age of 74 years, which should have reduced the number of subjects with positive screening. Uchida et al. (2003) ${ }^{22}$ obtained reasonable performance in the question used by them to stratify subjects by hearing loss level.

Gates et al. (1990) ${ }^{19}$ stated that hearing is poorly described through one single parameter, be it self-report or pure tone thresholds, and it is highly prevalent among elderly people and increases in older groups. Few studies with representative population samples used audiometry as a hearing assessment method. A population-based study allows generalization of results, provided that geographical areas, ethnics and noise exposure levels are the same. Studies based on convenience or clinical samples, with or without estimates derived from other geographical regions, may lead to false results concerning hearing loss. If the purpose of hearing loss measurement is to associate it with other factors, then knowledge of characteristic of mistakes comparing questionnaire and audiometry through validation study is quite convenient.

We should also add that we did not find any Brazilian studies that compared one single question questionnaire to pure tone audiometry, and we do not have estimates that can be generalized to the Brazilian population.

\section{CONCLUSION AND SUGGESTIONS}

One single global question has good performance to identify elderly people with hearing loss and it may be recommended for epidemiological studies that cannot apply audiometric measurements. Considering that we do not have estimates that can be generalized to the Brazilian population, it would be recommendable to conduct a validation study of one single global question compared to audiometry, allowing the use of this useful tool in Brazilian epidemiological studies, with the advantage of being able to study a large number of subjects.

\section{REFERENCES}

1. Carvalho JAM \& Garcia RA. O envelhecimento da população brasileira: um enfoque demográfico. Cad Saúde Pública 2003; 19 (Pt 3): 725-34.

2. Lima-Costa MF \& Veras R. Saúde pública e envelhecimento. Cad Saúde Pública 2003; 19 (Pt 3): 700-1.

3. Cruickshanks KJ, Wiley TL, Tweed TS, Klein BEK, Klein R, MaresPerlman JA \& Nondahl DM. Prevalence of hearing loss in older adults in Beaver Dam, Wisconsin. The epidemiology of hearing loss. Am J Epidemiol 1998; 148 (Pt 9): 879-86.

4. "Semana nacional de prevenção à surdez - prevenir é ouvir", 1997. Sociedade Brasileira de Otorrinolaringologia (SBORL). (http:/ /www.sborl.org.br). 
5. Bilton T, Ramos LR, Ebel S, Teixeira LS \& Tega LP. Prevalência da deficiência auditiva em uma população idosa. Mundo Saúde 1997; 21 (Pt 4): 218-25

6. Rozenfeld S. Reações adversas aos medicamentos em idosos: as quedas em mulheres como iatrogenia farmacoterapêutica [Dissertação]. Rio de Janeiro (RJ): Universidade do Estado do Rio de Janeiro; 1997.

7. Viude A. Fatores associados à presbiacusia em idosos. [Dissertação]. São Paulo (SP): Universidade de São Paulo; 2002.

8. Wu HY, Chin JJ \& Tong HMH. Screeening for hearing impairment in a cohort of elderly patients attending a hospital geriatric medicine service. Singapore Med J 2004; 45 (Pt 2): 79-84

9. Clark K, Sowers MR, Wallace RB, Jannausch ML, Lemke J, Anderson CV. Age-Related Hearing Loss and Bone Mass in a Population of Rural Women Aged 60 to 85 Years. Ann Epidemiol 1995; 5 (Pt 1): 8-14.

10. Zwerling C, Whitten PS, Davis CS \& Sprince NL. Occupational injuries among workers with disabilities. The National Health Interview Survey, 1985-1994. J Am Med Assoc 1997; 278 (Pt 24): 2163-9.

11. Appollonio I, Carabellese C, Frattola L \& Trabucchi M. Effects of sensory aids on the quality of life and mortality of elderly people: a multivariate analysis. Age ageing 1996; 25: 89-96.

12. Moore AA \& Siu AL. Screening for common problems in ambulatory elderly: clinical confirmation of a screening instrument. Am J Med 1996; 100: 438-43.

13. Gates GA, Murphy M, Rees TS, Fraher A. Screening for handicapping hearing loss in the elderly. J Fam Pract 2003; 52 (Pt 1): 56-62.

14. Nondahl DM, Karen JC, Wiley TL, Tweed TS, Klein R \& Klein BEK. Accuracy of self-reported hearing loss. Audiology 1998; 37: 295-301.

15. Sindhusake D, Mitchell P, Smith W, Golding M, Newall P, Hartley D \& Rubin G. Validation of self-reported hearing loss. The Blue Mountains Hearing Study. Int J Epidemiol 2001; 30: 1371-8.
16. Gomes MI, Hwang S, Sobotova L \& Stark AD. A comparison of self-reported hearing loss and audiometry in a cohort of New York farmers. J Speech Lang Hear Res 2001; 44: 1201-8.

17. Wilson, DH, Walsh, PG, Sanchez, L, Davis, AC, Taylor, AW, Tucker, G \& Meagher, I. The epidemiology of hearing impairment in an Australian adult population. Int J Epidemiol 1999; 28 (Pt 2): $247-$ 52 .

18. McCusker J, Bellavance F, Cardin S, Trepanier S \& The Identification of Seniors at Risk (ISAR) Steering Committee. Screening for geriatric problems in the emergency department: reliability and validity. Acad Emerg Med 1998; 5 (Pt 9): 883-93.

19. Gates, GA, Cooper, JC, Kannel, WB \& Miller, NJ. Hearing in the elderly: the Framingham cohort, 1983-1985. Part I. Basic audiometric test results. Ear Hear 1990; 11 (Pt 4): 247-56.

20. Clark K, Sowers M, Wallace RB \& Anderson C. The accuracy of self-reported hearing loss in women aged 60-85. Am J Epidemiol 1991; 134 (Pt 7): 704-8.

21. Reuben DB, Walsh K, Moore AA, Damesyn M \& Greendale GA. Hearing loss in community-dwelling older persons: national prevalence data and identification using simple questions. J Am Geriatric Soc 1998; 46: 1008-11.

22. Uchida Y, Nakashima T, Ando F, Niino N \& Shimokata H. Prevalence of self-perceived auditory problems and their relation to audiometric thresholds in a middle-aged to elderly population. Acta Otolaryngol 2003; 123: 618-26.

23. Voeks SK, Gallagher CM, Langer EH \& Drinka PJ. Self-reported hearing difficulty and audiometric thresholds in nursing home residents. J Fam Pract 1993; 36 (Pt 1): 54-8.

24. Hashimoto H, Nomura K \& Yano E. Psychosomatic status affects the relationship between subjective hearing difficulties and the results of audiometry. J Clin Epidemiol 2004; 57: 381-5. 